\title{
上顎前突の治療における機能的矯正装置と 咬合斜面板との効果の比較
}

\author{
九州霜科大学矯正学教室（主任：佐藤通泰教授） \\ 藤 田邦彦・永松ふみ子 \\ 夕田勉・佐藤通泰
}

昭和 54 年 5 月 28 日受付

Comparison between the Effects of Using the Activator and the Jumping Plate for Treatment of Maxillary Protrusion

\author{
Kunihiko Fujita, Fumiko Nagamatsu, \\ Tsutomu Yuuta and Michiyasu Sato \\ Department of Orthodontics (Chief : Prof. Michiyasu Sato) \\ Kyushu Dental College, Kitakyushu, Japan
}

With a view to studying the differences between the effects of using the activator and the jumping plate for treatment of maxillary protrusion accompanied by mandibular distocclusion and deep overbite, a series of examinations was conducted with 60 patients of eight to twelve years old, comprising 40 patients applied the activator and 20 patients applied the jumping plate. The changes in angles as well as in distances were measured by an X-ray cephalometer before and after the treatment, and the data thus obtained were statistically compared. The results were as follows:

1. In correction of overjet, maxillary incisors markedly tipped lingually in both cases of using the activator and the jumping plate, and no significant differences were observed between the uses of the two appliances in the changes before and after the treatment. On the other hand, for mandibular incisors, there were little changes by the use of the activator, while mandibular incisors tipped labially to a significant extent by the use of the jumping plate.

2. The mandibular plane angle and the ramus angle against the $S-N$ plane showed little changes by the use of the activator, while by the use of the jumping plate, those angles showed significantly great increases accompanied by back- and downward rotations of the mandible. Thus it can be induced that the use of the activator would cause parallel downward shift of the mandible, and the use of the jumping plate would cause changes accompanied by clockwise rotations of the mandible. 
粕喜

矯正治療に扔いて，下顎遠心咬合に過蓋咬合を伴った 上嵿前突症例にしばしば遭遇する。このような症例に は，下顎の近心移動と咬合の挙上を計らねばならず，こ のため, 筋の機能力を利用した機能的矯正装置（以下，

F.K.O.と略す) や咬合斜面板 (以下, 斜面板と略す), また機械的な力を用いた multibanded appliance な どによる治療が行われている.

機械的な multibanded appliance が普及した今日 においても，混合歯列期という成長発育の旺盛な時期に は，歯牙の萌出力や顎の成長発育を効果的に利用するた めに, F.K.O., 斜面板が多く用いられる.

斜面板は1877年，Kingsley によって創案され，その 原理を応用し, 1936年 Andresen, Häupl らにより F.K.O.が発表された。乙れら両装置は, 原理的には同 じであっても形態は勿論, 使用法にも相違があり, 從っ て治療効果にも当然相違があると考えられるが，現在ま でそれが明確にされていない。

そこで今回，著者らは雨装㯰の治療効果の相違を検索 し, 適応症の決定基準の一助とするために本研究を行っ た。

\section{研 究 方 法}

1. 資 料

九州歯科大学附属病院矯正科に来院の下顎遠心咬合に
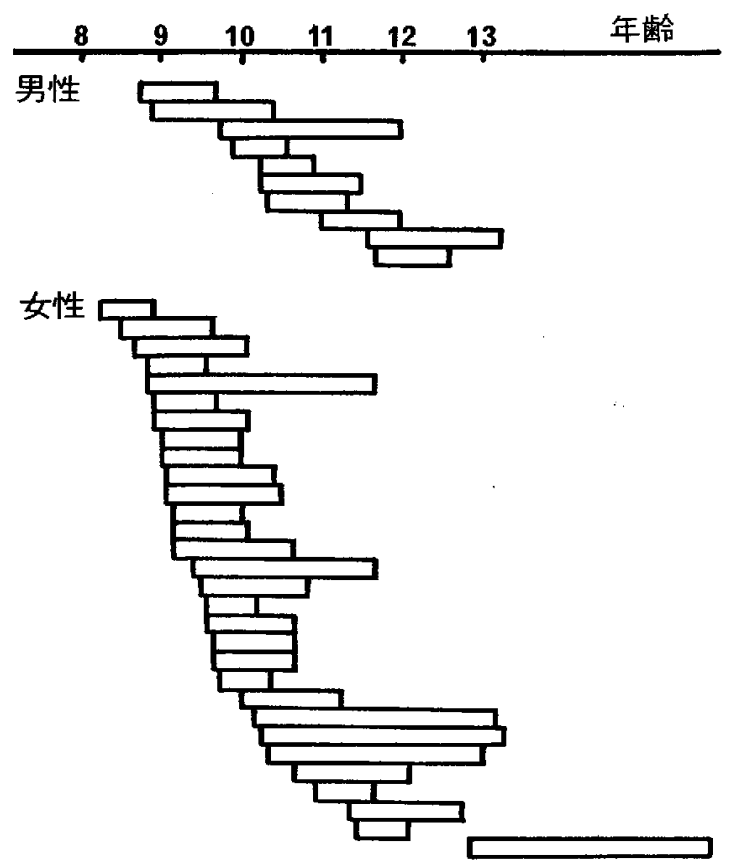

過蓋咬合を伴う上頢前突の患者で，F.K.O.，あるいは 斜面板のみを使用して治療を行った症例中，ほぼ同年代 の者を研究資料とした。なお，装置使用により生じたと 思われる dual bite 症例は除外した。

症例数は, F.K.O.症例が男子 10 名, 女子 30 名, 計 40 名, 斜面板症例は男子 6 名, 女子 14 名, 計 20 名である.

装置使用開始時年齢は, F.K.O. 症例は 8 才 3 力月か ら 12 才 10 力月, 平均 9 才 8 力月, 斜面板症例は 8 才 0 力 月から 12 才 4 力, 平均 9 才 8 力月であり, 装置使用期 間は, F.K.O.症例は, 最短 7 力月, 最長 36 力月, 平均 16 力月, 斜面板症例は, 最短 6 力月, 最長 34 力月, 平均 14カ月であった（図 1)。

\section{2 . 棓十測点および計測項目}

被験者の中心咬合位で装置使用前後の頭部 X線側貌規 格写真を透写し, 距離計测, 角度計測を行った。

a . 計測点 (※印は bilateral point)

$\mathrm{N}$ ：鼻骨・前頭骨縫合部の最前出点

$\mathrm{S}:$ トルコ鞍の中心点

$A r \%$ ：下顎関節突起後縁と外頭蓋底像との交点

A：上顎中切霜霜根尖付近の歯槽骨最陌山点

B : 下顎中切歯歯根尖付近の歯槽骨最陥凹点

$\mathrm{U} 1 ：$ 上顎中切歯切端

L1：下顎中切歯切端

6 ：上下第一大曰歯の咬頭嵌合の近遠心的中点 Pog：下頽下縁平面に対する顔隆起の最前出点 $\mathrm{Me}$ : 頣正中断面像の最下点

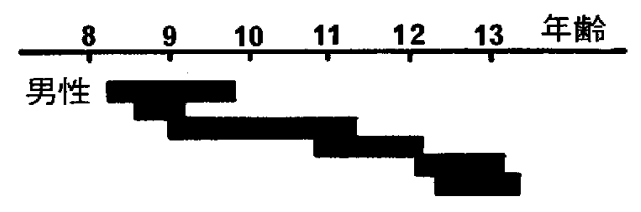

女性

F.K.O.

斜面板

図 1 被験者の装置装着時年秢之装置使用期間 


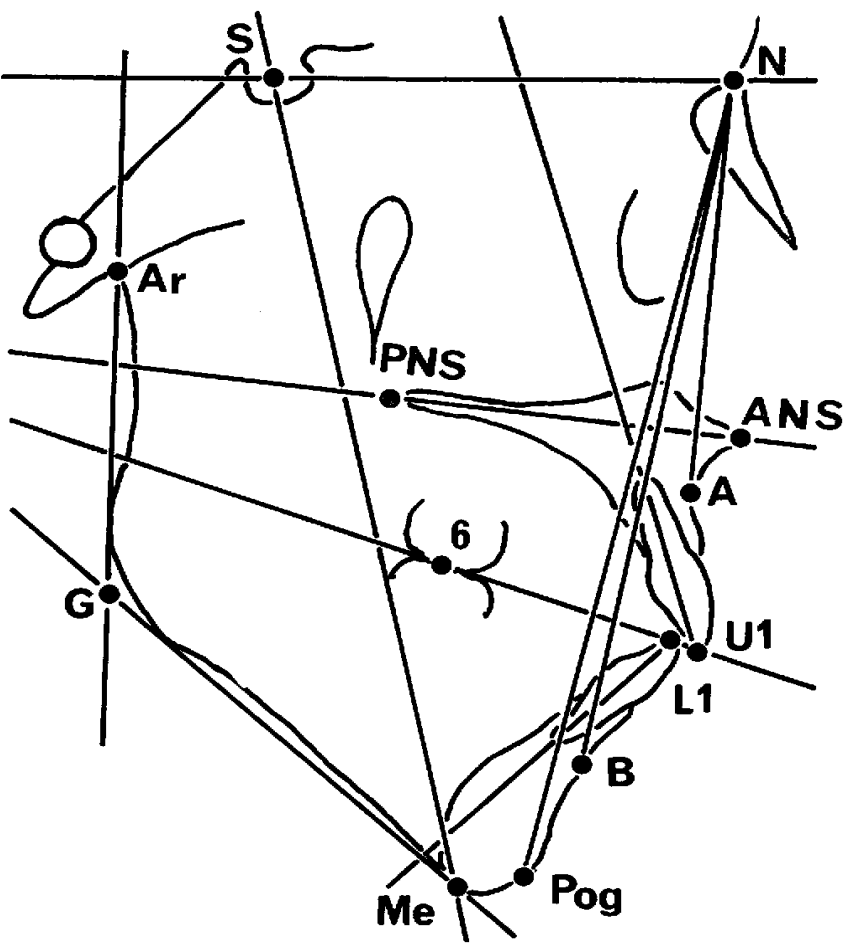

図 2 計測点および計測項目——角度計測——

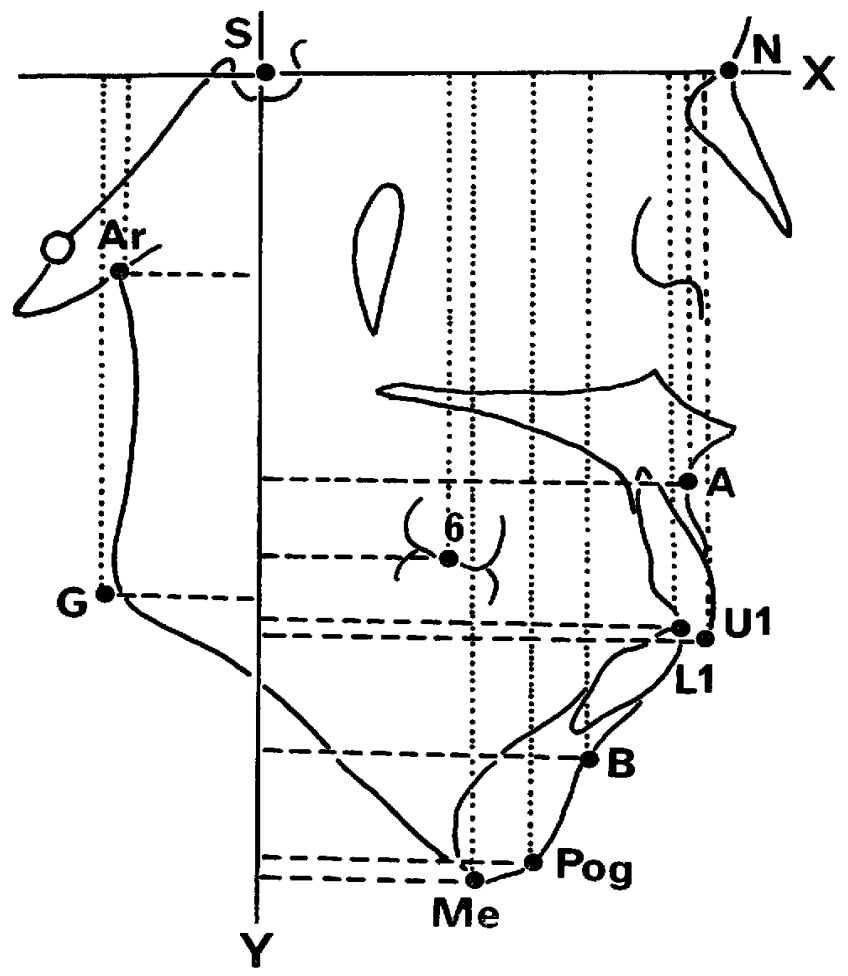

図 3 計測点および計測項目

一一垂直および水平距離計測——

$\mathrm{G}$ *：Ar を通る下顎枝後縁接線とMeを通る下顎下縁 接線との交点

ANS：前鼻棘の最尖端点

PNS：後舅棘の最尖端点

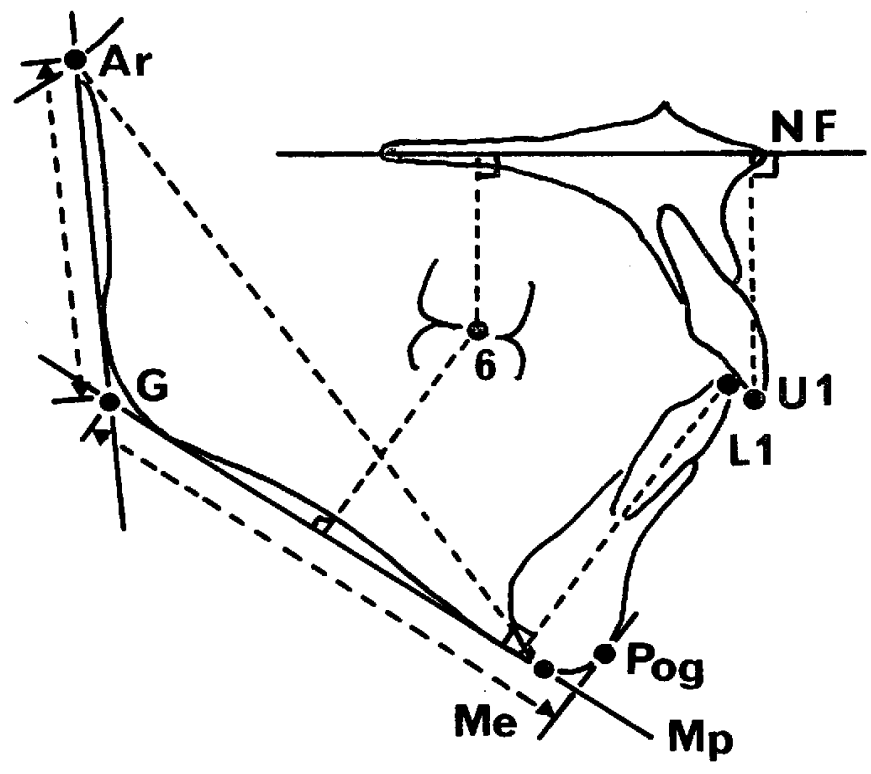

図 4 計測点抢よび計測項目 その他の距離計測- -

前記の13計測点から, 次の39項目について角度計測, 距離計測を行った。なお bilateral point はその 2 点 の中点在用いた。

b . 角度計測項目

図 2 亿示すごとく, $\angle \mathrm{SNA}, \angle \mathrm{SNB}, \angle \mathrm{ANB}, \angle \mathrm{S}$ $\mathrm{N}$ Pog, $\angle \mathrm{ArGMe}, \angle \mathrm{SN}-\mathrm{U} 1, \angle \mathrm{SN}-\mathrm{NF}(\mathrm{NF}$ ANS と PNSを結んだ線)， $\angle \mathrm{SN}-\mathrm{Occ}$. (Occ.は咬合 平面で上下中切歯切端間の中点と計測点 6 を結んだ線), $\angle \mathrm{SN}-\mathrm{Mp}(\mathrm{Mp}$ は $\mathrm{Me}$ Gを結んだ線)， $\angle \mathrm{SN}-\mathrm{ArG}$, $\angle \mathrm{SN}-\mathrm{SMe}, \angle \mathrm{Mp}-\mathrm{L} 1, \angle \mathrm{U} 1-\mathrm{L} 1$ の13項目を計測し た。

c . 距離計測

1）垂直および水平距離計測

図 3 亿示すごとくトルコ鞍の中心を $\mathrm{S}$ とし， S-N平面 を $\mathrm{X}$ 軸， $\mathrm{S}$ を通るその垂線を $\mathrm{Y}$ 軸として, 計測点 $\mathrm{U} 1$,

$\mathrm{A}, \mathrm{L1}, \mathrm{B}, \mathrm{Pog}, \mathrm{Me}, 6, \mathrm{Ar}, \mathrm{G}$ から $\mathrm{X}$ 軸への垂線 の長さをその計測点の垂直距離とし, 前記の計測点にN を加えた各点汃ら Y 軸への距離を水平距離として, 垂直 距離 9 項目，水平距離10項目を計測した。

2) その他の距離計測

図 4 亿示すごとくU1，6 から NFへの垂直距離として それぞれ NF-U1，NF-6 を，また L1，6から Mp へ の垂直距離としてそれぞれ NF-U1，NF-6 を，また L1， 6 から $\mathrm{Mp}$ への垂值距離としてそれぞれ $\mathrm{Mp}-\mathrm{L} 1$, Mp-6 を, さらに下顎体長として G-Pog, 下枵枝長と して Ar-G，下顎骨效果長として Ar-Me の 7 項目を 
計測した。

以上の計測にあたって, 角度計測は直径 $8.5 \mathrm{~cm}$ の分度 器を用いて0.5度まで, 距離計測は $1 / 20 \mathrm{~mm}$ 副尺付ノギ スを用いて1/10mmまで測定した。

\section{3. 統計的処理}

F.K.O. と斜面板症例の変化量の相違を調查するため に次の統計処理を行った。な抢角度，距離計測に扔いて 増大した場合を十，娍少した場合を一とした。

年間変化量を $\mathrm{X}$, 資料数を $\mathrm{N}$ とすると

年間平均変化量 $\quad \bar{X}=\frac{\sum X}{N}$

平均值の分散 $\quad \mathrm{S}^{2}=\frac{\sum \mathrm{X}^{2}-\mathrm{N}(\overline{\mathrm{X}})^{2}}{\mathrm{~N}-1}$

平均值の標準誤差 S.E.M. $=\sqrt{\frac{\mathrm{S}^{2}}{\mathrm{~N}}}$

平均値の差の検定 $\mathrm{t}_{0}=\frac{\overline{\mathrm{X}}_{1}-\overline{\mathrm{X}}_{2}}{\sqrt{\mathrm{S}_{1}+\mathrm{S}_{2}}}$

両群の分散に著しい差が認められるときは, CochranCox の近似法による検定を行った。すすなわち

$$
t_{c}=\frac{\frac{S_{1}^{2}}{N_{1}} t_{1}+\frac{S_{2}^{2}}{N_{2}} t_{2}}{\frac{S_{1}^{2}}{N_{1}}+\frac{S_{2}^{2}}{N_{2}}}
$$

但し， $\mathrm{t}_{1}, \mathrm{t}_{2}$ とは自由度 $\mathrm{N}_{1}-1, \mathrm{~N}_{2}-1$ の，それぞれの 有意水準の $\mathrm{t}$ 值で, $\left|\mathrm{t}_{\mathbf{0}}\right|>\mathrm{t}_{\mathrm{c}}$ のとき有意差ありとした

有意性の検定は次の有意水準によった。

95\% 99\% 有意である\%

99\%以上 明らかに有意である※※

\section{成}

\section{䋶}

\section{1. 角度変化}

角度計測值においては表 1 に示すように $\angle \mathrm{SN}-\mathrm{Mp}$, $\angle \mathrm{SN}-\mathrm{SMe}$ ，执よび $\angle \mathrm{Mp}-\mathrm{L} 1$ に99\%の有意水準で斜面 板症例が F. K. O. 症例に比へて増大した。 また， $\angle \mathrm{SN}-\mathrm{Occ} ., \angle \mathrm{SN}-\mathrm{ArG}$ に扔いても95\%の有意水準で 同㥞の結果を示した。

F. K. O. 症例の $\angle \mathrm{ANB}$ の変化量は $95 \%$ 水準で斜面 板症例ょり有意に減少した。その他の計測項目はすべて $\mathrm{F} \cdot \mathrm{K} \cdot \mathrm{O}$. 症例と 斜面板症例との間に有意差はみられな かった。

\section{2. 垂直距離変化}

表 2 亿示すように垂直距離計測においては, SN-L1 に95\%の有意水準で斜面板症例が F.K. O. 症例に比心 て大きく増大したが，その他の計測項目においては，
表1 F.K.O. 症例と斜面板症例の年間角度翂化量の比較

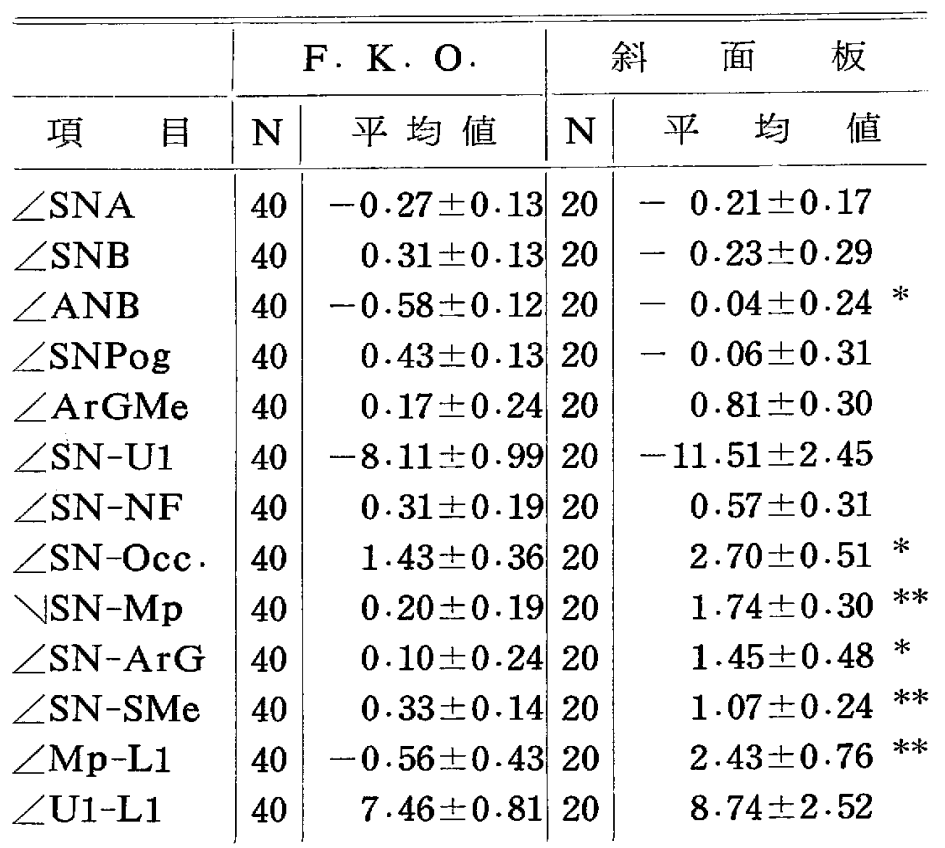

土以下は平均值の標準誤差（S.E.M.）を示す. *，**，はそれぞれ，95\%，99\%の有意水準で $\mathrm{F}$. $\mathrm{K} . \mathrm{O}$. 症例と斜面板症例の年間成長変化に, 有意差 があるととを示す．単位は度である．

表 2 F.K. O . 症例と斜面板症例の年間垂直距離変 化量の比較

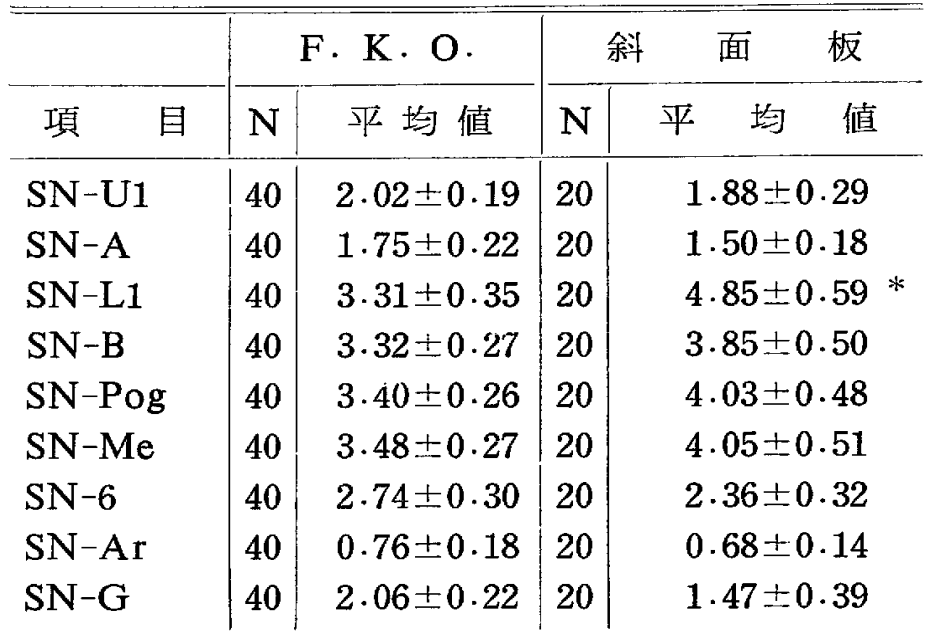

土以下は平均值の標準誤差（S. E. M.）を示す. *，**，はそれぞれ，95\%，99\%の有意水準で F. $\mathrm{K} \cdot \mathrm{O}$. 症例之斜面板症例の年間成長変化に, 有意差 があることを示す，単位は mmである.

F. K . O . 症例と斜面板症例間に有意な差は認められな かった。しかし，覧正中断面像上の点， $\mathrm{B}, \mathrm{Pog}, \mathrm{Me}$ 等 は両症例間に有意差は認められなかったが，F．K．O． 症例に比べて斜面板症例の方が増大した結果を示した。 
表 $3 \mathrm{~F} \cdot \mathrm{K}$ ， O．症例之斜面板症例の年間水平距離変 化量の比較

\begin{tabular}{|c|c|c|c|c|c|c|}
\hline & \multicolumn{2}{|r|}{ F. K. O. } & \multicolumn{2}{|c|}{ 斜 } & 面 & \multirow{2}{*}{$\begin{array}{l}\text { 板 } \\
\text { 値 }\end{array}$} \\
\hline 項 & $\mathrm{N}$ & 平均值 & $\mathrm{N}$ & 平 & 均 & \\
\hline $\mathrm{S}-\mathrm{N}$ & 40 & $0.81 \pm 0.09$ & 20 & \multicolumn{3}{|c|}{$0.69 \pm 0.12$} \\
\hline S-U1 & 0 & $-2.45 \pm 0.38$ & 20 & \multicolumn{3}{|c|}{$-3.10 \pm 0.67$} \\
\hline $\mathrm{S}-\mathrm{A}$ & 40 & $0.15 \pm 0.17$ & 20 & \multicolumn{3}{|c|}{$0.34 \pm 0.28$} \\
\hline S-L1 & & $0.44 \pm 0.22$ & 20 & \multicolumn{3}{|c|}{$0.99 \pm 0.42$} \\
\hline$S-B$ & 40 & $0.64 \pm 0.23$ & 20 & \multicolumn{3}{|c|}{$-0.20 \pm 0.52$} \\
\hline S-Pog & 40 & $0.69 \pm 0.22$ & 20 & \multicolumn{3}{|c|}{$-0.63 \pm 0.57 *$} \\
\hline $\mathrm{S}-\mathrm{Me}$ & 40 & $0.61 \pm 0.27$ & 20 & \multicolumn{3}{|c|}{$-1.43 \pm 0.53 *$} \\
\hline$S-6$ & 40 & $1.64 \pm 0.26$ & 20 & \multicolumn{3}{|c|}{$0.35 \pm 0.41$} \\
\hline $\mathrm{S}-\mathrm{Ar}$ & 40 & $0.81 \pm 0.18$ & 20 & \multicolumn{3}{|c|}{$0.39 \pm 0.16$} \\
\hline$S-G$ & 40 & $1.19 \pm 0.31$ & 20 & \multicolumn{3}{|c|}{$1.21 \pm 0.38$} \\
\hline
\end{tabular}

士以下は平均值の標準誤差（S. E. M.）を示す. *，**，はそれぞれ，95\%，99\%の有意水準で $\mathrm{F}$. $\mathrm{K} \cdot \mathrm{O}$. 症例と斜面板症例の年間成長変化に，有意差 があることを示す．単位はmmである．

\section{3. 水平距離変化}

表 3 亿示すように水平距離計測に抢いては，S-Meに 99\%の有意水準で差が認められ，F．K．O. 症例は十の 変化，斜面板症例は一の変化が認められた。また，S-6 においても $99 \%$ 有意水準で F.K. O. 症例が斜面板症 例よりも大きく増大した変化を示した．S-Pogでは95\% の有意水準で差が認められ，F，K．O. 症例は十の変化

表 4 F. K . O. 症例と斜面板症例のその他の年間距 離変化量の比較

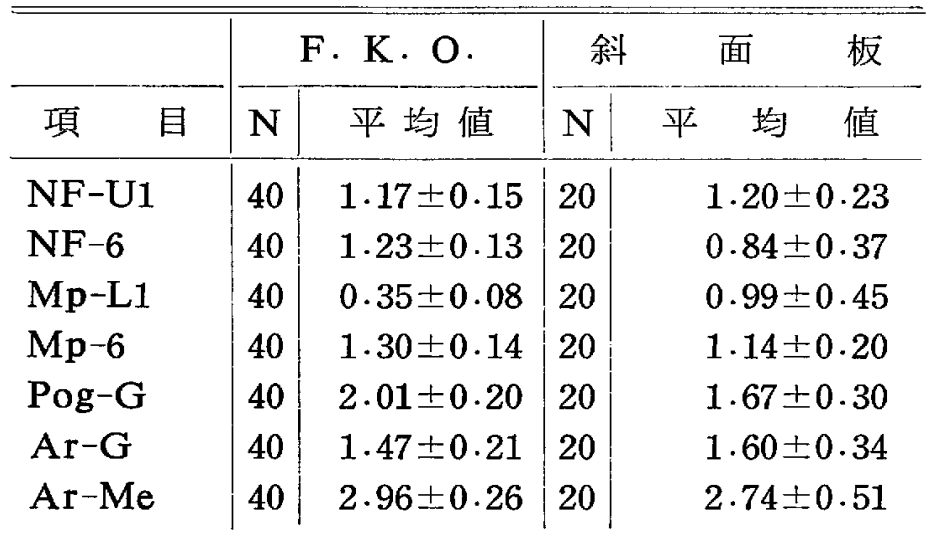

士以下は平均值の標準誤差（S. E.M.）を示す. *，**，はそれぞれ，95\%，99\%の有意水準で F. K. O. 症例之斜面板症例の 年間成長変化任, 有意 差があるととを示す．単位はmmである.
を，斜面板症例は一の変化を示した。その他の計測項目 については，F．K．O. 症例と斜面板症例閒に有意差は 認められなかった。

\section{4. その他の距離変化}

表 4 に示すように距離計測 2)においては，F，K．O. 症例と斜面板症例間に有意な差は認められなかった。

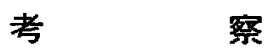

1. 装置使用に対する検討

装置使用時間に関しては，斜面板は口腔清掃時以外は 一日中，食事中も使用するように指示し，F．K．O．は できるだけ長時間使用させた。一日中使用している斜面 板に較べて，F．K．O．は問診によると約 14 時間前後の 使用であり，両者間の装置使用時間にかなりの差がある ものと思われる。

装置の構造に関しては, 斜面板は使用法により多少の 差違があり，可及的に下顎の前方移動と咬合の挙上を計 るものと，徐々に行うものとでは，斜面の形態に違いが ある.また F.K.O.におおても咬合の挙上のために， 曰蒾部咬合面のレジンを削除する方法や，上下前柬部切 端をレジン床部に咬合させる方法があり，用法の違いが あるが，今回の調查では，装置使用法に対する基準は設 定しなかった。

表5 F. K. O. 症例と斜面板症例の治療前の角度の比較

\begin{tabular}{|c|c|c|c|c|}
\hline & \multicolumn{2}{|c|}{ F. K. O. } & 斜 & 面 \\
\hline 項 & $\mathrm{N}$ & 平均 值 & $\mathrm{N}$ & 均 \\
\hline$\angle \mathrm{SNA}$ & 40 & $81.31 \pm 0.53$ & 20 & $81.68 \pm 0.72$ \\
\hline$\angle \mathrm{SNB}$ & 40 & $74.85 \pm 0.54$ & 20 & $75.85 \pm 0.54$ \\
\hline$\angle \mathrm{ANB}$ & 40 & $6.48 \pm 0.33$ & 20 & $5.83 \pm 0.56$ \\
\hline$\angle$ SNPog & 40 & $74.19 \pm 0.53$ & 20 & $75.75 \pm 0.54$ \\
\hline$\angle \mathrm{ArGMe}$ & 40 & $126.40 \pm 1.04$ & 20 & $124 \cdot 70 \pm 1.37$ \\
\hline$\angle \mathrm{SN}-\mathrm{U} 1$ & 40 & $110.21 \pm 1.19$ & 20 & $111.58 \pm 1.86$ \\
\hline$\angle \mathrm{SN}-\mathrm{NF}$ & 40 & $8.30 \pm 0.55$ & 20 & $8.35 \pm 0.68$ \\
\hline$\angle \mathrm{SN}-\mathrm{Occ}$. & 40 & $19.85 \pm 0.61$ & 20 & $18.48 \pm 0.82$ \\
\hline$\angle \mathrm{SN}-\mathrm{Mp}$ & 40 & $38.56 \pm 0.89$ & 20 & $37.03 \pm 1.16$ \\
\hline$\angle \mathrm{SN}-\mathrm{ArG}$ & 40 & $92.71 \pm 0.86$ & 20 & $92 \cdot 15 \pm 1 \cdot 15$ \\
\hline$\angle \mathrm{SN}-\mathrm{SMe}$ & 40 & $74.43 \pm 0.59$ & 20 & $73.00 \pm 0.62$ \\
\hline$\angle \mathrm{Mp}-\mathrm{L} 1$ & 40 & $97.28 \pm 0.93$ & 20 & $91.85 \pm 1.75 *$ \\
\hline$\angle \mathbf{U} 1-\mathrm{L} 1$ & 40 & $113.96 \pm 1.29$ & 20 & $119.93 \pm 2.45 *$ \\
\hline
\end{tabular}

士以下は平均值の標準誤差（S.E.M.）を示す. *，**，はそれぞれ，95\%，99\%の有意水準で $\mathrm{F}$.

$\mathrm{K} \cdot \mathrm{O}$. 症例と斜面板症例の年間成長変化に, 有意差 があるととを示す．単位は度である。 
表 6 F $\cdot \mathrm{K} \cdot \mathrm{O}$. 症例と斜面板症例の治療前の垂直距 離の比較

\begin{tabular}{|c|c|c|c|c|}
\hline & & $\mathrm{K} \cdot \mathrm{O}$. & 斜 & 面 \\
\hline 項 & $\mathrm{N}$ & 平均值 & $\mathbf{N}$ & 平 \\
\hline SN-U1 & 40 & $75.51 \pm 0.79$ & 20 & $75.85 \pm 0.96$ \\
\hline SN-A & 40 & $53.71 \pm 0.73$ & 20 & $53.75 \pm 0.76$ \\
\hline SN-L1 & 40 & $71.04 \pm 0.87$ & 20 & $70.05 \pm 0.87$ \\
\hline SN-B & 40 & $87.44 \pm 0.70$ & 20 & $88.63 \pm 0.99$ \\
\hline SN-Pog & 40 & $100.75 \pm 0.85$ & 20 & $102.00 \pm 1.27$ \\
\hline $\mathrm{SN}-\mathrm{Me}$ & 40 & $102.64 \pm 0.80$ & 20 & $104.00 \pm 1.17$ \\
\hline $\mathrm{SN}-6$ & 40 & $61.68 \pm 0.60$ & 20 & $62.23 \pm 1.04$ \\
\hline $\mathrm{SN}-\mathrm{Ar}$ & 40 & $25.56 \pm 0.54$ & 20 & $26.93 \pm 0.58$ \\
\hline $\mathrm{SN}-\mathrm{G}$ & 40 & $64.19 \pm 0.65$ & 20 & $66.43 \pm 1.31$ \\
\hline
\end{tabular}

土以下は平均值の標準詋差 (S. E. M.) を示す. *，**，はそれぞれ，95\%，99\%の有意水準で $\mathrm{F}$. $\mathrm{K} \cdot \mathrm{O}$. 症例と斜面板症例の年間成長変化に, 有意差 があることを示す．単位はmmである.

表 7 F.K. K. 症例と斜面板症例の治療前の水平距 離の比較

\begin{tabular}{|c|c|c|c|c|c|c|}
\hline \multirow[b]{2}{*}{ 項 } & \multirow[b]{2}{*}{ 目 } & \multicolumn{2}{|c|}{ F. K. O. } & 斜 & 面 & \multirow{2}{*}{$\frac{\text { 板 }}{\text { 值 }}$} \\
\hline & & $\mathrm{N}$ & 平均 值 & $\mathbf{N}$ & 均 & \\
\hline$S-N$ & & 40 & $64.08 \pm 0.47$ & 20 & \multicolumn{2}{|c|}{$64.18 \pm 0.69$} \\
\hline S-U1 & & 40 & $58.38 \pm 0.79$ & 20 & \multicolumn{2}{|c|}{$58.93 \pm 0.85$} \\
\hline$S-A$ & & 40 & $55.78 \pm 0.51$ & 20 & \multicolumn{2}{|c|}{$56.30 \pm 0.64$} \\
\hline S-L1 & & 40 & $52.05 \pm 0.77$ & 20 & \multicolumn{2}{|c|}{$52.54 \pm 0.79$} \\
\hline S-B & & 40 & $39.74 \pm 0.86$ & 20 & \multicolumn{2}{|c|}{$41.93 \pm 0.88$} \\
\hline S-Pog & & 40 & $35.43 \pm 1.01$ & 20 & \multicolumn{2}{|c|}{$38.20 \pm 1.13$} \\
\hline $\mathrm{S}-\mathrm{Me}$ & & 40 & $29.70 \pm 0.99$ & 20 & \multicolumn{2}{|c|}{$31.00 \pm 1.15$} \\
\hline$S-6$ & & 40 & $22 \cdot 31 \pm 0.66$ & 20 & \multicolumn{2}{|c|}{$23.45 \pm 0.60$} \\
\hline $\mathrm{S}-\mathrm{Ar}$ & & 40 & $18.19 \pm 0.46$ & 20 & \multicolumn{2}{|c|}{$17.23 \pm 0.62$} \\
\hline$S-G$ & & 40 & $19.73 \pm 0.74$ & 20 & \multicolumn{2}{|c|}{$18.83 \pm 0.96$} \\
\hline
\end{tabular}

士以下は平均值の標準䛈差（S. E. M.）を示す. *，**，はそれぞれ，95\%，99\%の有意水準で $\mathrm{F}$.

K. O. 症例と斜面板症例の 年間成長変化に, 有意 差があるととを示す．単位は mmである。

2. F. K. O. 症例と斜面板症例の治療前の比較

F.K. O. と斜面板使用による両者間の治療変化の相 違を検討するには，装置使用前の患者に形態的相違があ るか否かを検討しておく必要がある。

表 5，6，7，8は F. K. O. 症例と斜面板症例の治
表 8 F.K. K. O. 症例と斜面板症例の治療前のその他 の距離の比較

\begin{tabular}{|c|c|c|c|c|c|c|}
\hline & \multicolumn{2}{|c|}{ F. K. O } & \multicolumn{2}{|c|}{ 斜 } & \multirow{2}{*}{$\begin{array}{l}\text { 面 } \\
\text { 均 }\end{array}$} & \multirow{2}{*}{$\frac{\text { 板 }}{\text { 值 }}$} \\
\hline 項 & $\mathrm{N}$ & 平均 值 & $\mathbf{N}$ & 平 & & \\
\hline NF-U1 & 40 & $27 \cdot 56 \pm 0.35$ & 20 & \multicolumn{3}{|c|}{$26.55 \pm 0.50$} \\
\hline$N F-6$ & 40 & $18.59 \pm 0.35$ & 20 & \multicolumn{3}{|c|}{$18 \cdot 30 \pm 0.45$} \\
\hline $\mathrm{Mp}-\mathrm{L} 1$ & 40 & $40 \cdot 19 \pm 0.48$ & 20 & \multicolumn{3}{|c|}{$39.03 \pm 0.66$} \\
\hline Mp-6 & 40 & $28.56 \pm 0.37$ & 20 & \multicolumn{3}{|c|}{$28.68 \pm 0.48$} \\
\hline Pog-G & 40 & $66.37 \pm 0.62$ & 20 & \multicolumn{3}{|c|}{$67 \cdot 30 \pm 1.01$} \\
\hline$A r-G$ & 40 & $38.74 \pm 0.51$ & 20 & \multicolumn{3}{|c|}{$39.38 \pm 1.22$} \\
\hline $\mathrm{Ar}-\mathrm{Me}$ & 40 & $90.69 \pm 0.73$ & 20 & \multicolumn{3}{|c|}{$91.20 \pm 1.13$} \\
\hline
\end{tabular}

土以下は平均值の標準誤差（S. E. M.）を示す.

*，**，はそれぞれ，95\%，99\%の有意水準で F.

K. O. 症例と斜面板症例の年閒成長変化に，有意

差があることを示す．単位はmmである。

療前の測定值を比較したもので, 表 5 の角度計測項目で は，Mp-L1 において F.K. O. 症例の方が斜面板症例 よりも約 5.5 度大きく, 99\%の有意水準で下顎中切菌が

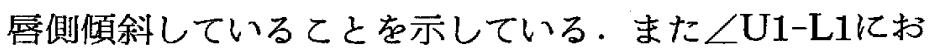
いては斜面板症例の方が F.K. O. 症例よりも約 6 度大 きい值を示し，95\%の有意水準で上下前歯歯軸角が大き いことを示している. その他の計測項目においては，F. K.O. 症例と斜面板症例間には有意な差は認められなか った。

垂直距離計測（表 6)，水平距離計測（表 7）距離計 測 2）（表 8）に扔いては，F．K．O. 症例と斜面板症例 との間には有意な差は認められなかった。

以上の結果より矯正治療前において，F，K．O. 症例 は斜面板症例に比べて下顎前歯が唇側に傾斜し, Interincisal Angle は小さい值を示したが, Skeletal pattern に扔いては両症例間には有意差は䜑められなかっ た。

\section{3. 成績について}

a . 上下顎中切䨑の変化について

下澦中切䨑の 増秢的変化について 飯塚 (1958) ${ }^{1}$, , 大 西 $(1969)^{2)}$, 山内 $(1972)^{3)}$ らは成長に伴って唇側傾斜 が強くなることを日本人学童について報告している。乙 れらの報告での唇側傾斜度は年間 1 度以内であって，本 研究での斜面板症例では 年間平均 2.4度と, 成長に伴う 変化よりも大きい值を示し, 斜面板による唇側傾斜が起 ったものと考えられる．神山 $(1964)^{4)}$, 曾根 $(1966)^{5}$ らは上䪶前突症例に斜面板を用いた結果, ほとんどの症 
例において下顎前歯の唇側傾斜が認められたと報告して 抢り，本研究も同様の知見を得た。しかし，中甸 $(1977)^{6}$ は斜面板による唇側傾斜の助長に対して必ずしも肯定的 ではない，ての知見の差違は資料の違い，および下饋前 函が唇側储斜しないように斜面に step をつけるなどの 装置の構造上の相違からきているものと推察される.

一方，F．K．．症例においては，下硕前歯部に唇側 誘導線が接するために，下顎前雬部の唇側傾斜が防止さ れ, さらには, 積極的に舌側移動を行った症例もあり, 結果として年閒 0.5 度という僅かではあるが舌側傾斜が みられた。

水平距離計測 S-L1 に打いても，F．K．O．症例より 斜面板症例の方が大きく前方へ変化していることから， 斜面板は下顎前崡の唇側傾斜を助長させるものと考えら れる。

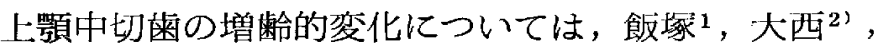
中島 ${ }^{3)}$ らは成長に伴って唇側傾斜が強くなることを日本 人学童を用いて報告している。本研究資料の上䫈前突症 例においては， $\angle \mathrm{SN}-\mathrm{U} 1$ は治療前では平均 111 度と著

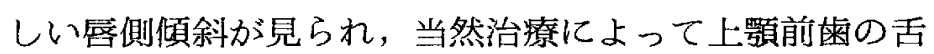
側移動が行われるために, 治袙後の $\angle \mathrm{SN}-\mathrm{U} 1$ の著しい 減少が羿められた。乙れらの変化において，F．K．O.， 斜面板による有意差は認められなかった。

前述の上下顎中切䨑の変化により，F．K．O. 弪例， 斜面板症例ともに $\angle \mathrm{U} 1-\mathrm{L} 1$ は増大し, over jet も致善 されている.

\section{b . 上下頼骨の前後的変化について}

上顎骨の発育について 飯塚 ${ }^{\prime \prime}$ は Hellman の 歯牙年

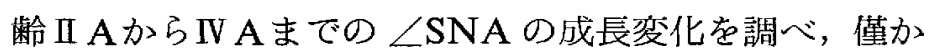
であるが増大することを示しているが，本研究において は, F. K. O. 症例, 斜面板症例ともに $\angle \mathrm{SNA}$ の減少 在示し，水平距離計測（表 3 ）においても，S-N の前方 成長量よりも $\mathrm{S}-\mathrm{A}$ の前方成長量の方が小さな值を示し た. 中島 ${ }^{6}$, Mearch $(1966)^{7}$ らの報告も同㴍な傾向を 示しており，F．K．．，斜面板ともに A 点の前方発青 に何らかの抑制力を与えるものと推察される。しかし， F. K. O. 症例, 斜面板症例間には有意な差は認められ なかった。

下疑骨の前後的変化をみた $\angle \mathrm{SNB}, \angle \mathrm{SNPog}$ み, 飯 塚 ${ }^{1}$ ，大西 ${ }^{2}$ ，中島 ${ }^{63}$ らの報告によると僅かながら前方 八の変化(角度の増大) が示されている. 表 1 $\angle \mathrm{SNPog}$ では，F．K．O. 症例では僅かな角度の増大が みられ，一方，斜面板症例では減少が翟められた。しか し，両装置間に有意差は示さなかった。水平距離計測
（表3）において，F.K.O. 症例では，S-B，S-Pog， $\mathrm{S}-\mathrm{Me}$ ともに前方への変化を示したが，斜面板症例では 後退を示し, S-Pog では95\%, S-Me では99\%の水準で F. K. O. 症例, 斜面板症例間に有意な差が琶められた. 三浦 $(1961)^{8)}$ は上影前突聇例に F. K . O. を用いて $\angle$ SNB の変化を計測し, 増加する症例と変化しない症 例とがあると報告し，増加した症例は F．K．O．による

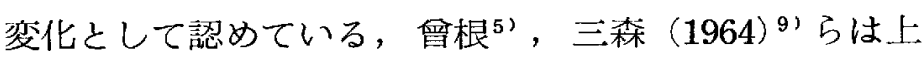
顎前突症例に斜面板を用いて治療した結果， $\angle \mathrm{SNB}$ 娍 少を䛱めて報告している。乙れらの報告等を考慮に入れ ると，F．K．O．は下頷骨の前方への変化を示し, 斜面 板は後退の変化が現われるものと考えられる，

$\angle \mathrm{SNB}$ の変化に大きく左右する因子として $\angle \mathrm{SN}-\mathrm{Mp}$ がある. $\angle \mathrm{SN}-\mathrm{Mp}$ が増大すると $\angle \mathrm{SNB}$ は減少し， $\angle \mathrm{SN}-\mathrm{Mp}$ が娍少すると $\angle \mathrm{SNB}$ は増大する。飯塚”は $\angle \mathrm{SN}-\mathrm{Mp}$ はII Cから IV A の間で年間平均約 0.4度増大 すると報告している。本研究においては表 1 に示すでと く，F．K．．．症例では, 年間平均 0.20 度, 斜面板症例 では年間平均1.74度の増加があり，両症例間に大きな相 違があり，その差は99\%以上の有意水準であった，又， $\mathrm{S}-\mathrm{N}$ 平面に対する下䪽枝の角度 $\angle \mathrm{SN}-\mathrm{ArG}$ において は，F．K．O. 症例では増大量が年間平均0.10度とほと んど変化なく, 一方, 斜面板症例では年間平均 1.45 度之 大きく増大し，両装置による変化は95\%の有意水準で差 違が認められた。

垂直距離計測（表 2) における SN-Me では，F，K． O. 症例よりも斜面板症例の方が增大したのに対して, SN-G では斜面板症例よりも F. K. O. 症例の方か増大 している.

これら下㖽骨の变化における测定值より，F．K．O. は下顎関節部の成長変化を伴って下顎下縁がほぼ平行に 下降しているが，斜面板は下顎下縁平面角の堌大，即ち 下㖽の後下方への回転をおこしており，そのため $\angle \mathrm{SNB}$ の減少 (B点の後退) が現われたものと推祭される.

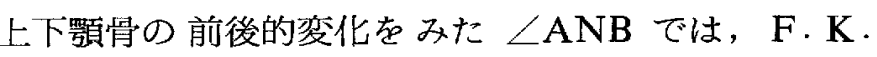
O. 症例では前述のごとく $\angle \mathrm{SNA}$ の減少, $\angle \mathrm{SNB}$ の 増加により $\angle \mathrm{ANB}$ は年間平均0.58度（表 1) 減少して いる. 一方，斜面板症例は $\angle \mathrm{SNA}, \angle \mathrm{SNB}$ ともに減 少し， $\angle \mathrm{ANB}$ は年間平均0.04度（表 1 ）の減少值を示 している.この って F.K.O. 症例が斜面板症例よりも大きかった。よ って，上下顎骨の前後的改善には F.K.O. が斜面板上 りもより有効であると思われる。

c. 咬合挙上について 
咬合举上のメカニズムについては上下顎前柬部の圧

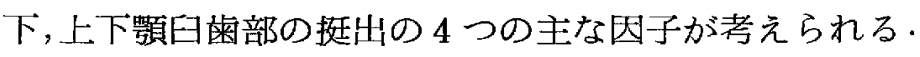
従来より咬合挙上の メカニズムについて，曾根 ${ }^{5}$ ， Bahador $(1944)^{10}{ }^{1}$, 矢野 $(1964)^{11}$ ，小森 $(1970)^{121}$, 中島（1977） ${ }^{13)}$ らにより種々異った報告が行われている が未だに統一した見解は出ていない。また，てれらの報 告は単一な装置による咬合挙上のメカニズムについて検 討されているのであるが, 本研究では F.K.O. と斜面 板との咬合挙上のメカニズムの相違について検討してみ た。

距離計測 2）（表 4 ）によると，上顎中切歯高径 NF-U1 に扔いては，F.K.O. 症例では年閒平均 $1.17 \mathrm{~mm}$, 斜 面板症例では年間平均 $1.20 \mathrm{~mm}$, その差 $0.03 \mathrm{~mm}$ と僅か に斜面板症例の方が大きい. しかし, 表 1 の $\angle \mathrm{SN}-\mathrm{U} 1$ の変化量を考慮すると, 雨装置が上顎中切歯へ及ぼす垂 直的変化の相違はほとんどないものと思われる。

下額中切歯高径 Mp-L1 の増加量に扔いては，F．K． O. 症例では年間平均 $0.35 \mathrm{~mm}$, 斜面板症例では年間平 均 $0.99 \mathrm{~mm}$ と $0.64 \mathrm{~mm}$ 斜面板症例の 方が大きい. 中 島 ${ }^{13)}$ ，坂本 $(1963)^{14}$ ) 弓の 同様な測定法での一般人の 年間成長量が $1 \mathrm{~mm}$ 以上であること, 又, 表 1 の $\angle \mathrm{Mp}-$ L1 の変化量を考慮すると，F．K．O.は斜面板よりも 下顎中切䨑高径の增大们何らかの抑制力が働くものと推 察される.

上顎第一大曰柬高径 $\mathrm{NF}-6$ の 増加量においては，F． $\mathrm{K} . \mathrm{O}$. 症例では年間平均 $1.23 \mathrm{~mm}$, 斜面板症例では年間

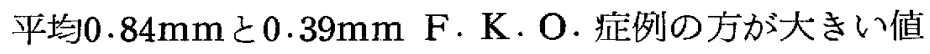
を示した。また，下顎第一大四歯高径 $\mathrm{Mp}-6$ の増加量 に扔いても，F．K.O. 症例では年間平均 $1.30 \mathrm{~mm}$, 斜

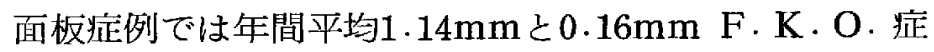
例の方が大きい值を示した．F．K．O. 症例の方が上下 顎第一大画の挺出量が大きかったにもかかわらず，表 1に示したように $\angle \mathrm{SN}-\mathrm{Occ}$. の変化は, 斜面板症例 の方が F.K.O. 症例よりも有意差をもって開大し，ま た， $\angle \mathrm{SN}-\mathrm{Mp}$ の変化は, F.K.O.症例で年間平均 0.20 度と僅かな変化しか示さなかったととは，F．K．O. 症 例は下顎関節部の成長変化が伴った結果と思われる。

前述の咬合挙上に朽ける4つの因子は，F．K．O．， 斜面板症例間には有意な差は示さなかったが，両症例に よる盿合の挙上の相違は個々の因子が累積して現われた ものと考えられる。

\section{結論}

下顎遠心咬合に過蓋咬合を伴った上頻前突症例に，
F．K．O．おうよび斜面板を使用したとき，両装置間の治 療効果の相違を研究するために，8才から12才までの斜 面板使用者 20 名，F．K. O. 使用者 40 名対象に，頭部 $\mathrm{X}$ 線側貌規格写真を用いて治療前後の角度変化, 距離変 化を調へ，統計的に比較した結果，次のような知見を得 た。

1. 斜面板，F，K．O. 両装置の使用による被蓋の改善 において，上顎前雨に対しては両装置間に有意差は誌 められなかったが，著しい舌側傾斜がみられた。一 方，下䅡前歯に関しては，F．K．O. 症例はほとんど 変化なく, 斜面板症例は有意差をもって唇側傾斜が認 められた。

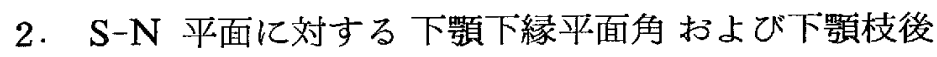
縁の角度は，F．K．O. 症例ではほとんど変化を示さ なかったが，斜面板症例では有意差をもって大きく変 化し，下蕷骨の後下方への回転が認められた。よって F．K．O．は下顎骨が下方へ平行に下降し，斜面板は clockwise rotation 老伴う変化を生ずるととがわか った.

\section{文献}

1. 飯塚哲夫 : 頭部 $X$ 線規格写真法による日本人小児の 顔の成長に関する研究, 口病誌 $25: 260-272$ ， 1958.

2. 大西 馨：学童期における上下顎雬槽基底部と中切 歯傾斜度との関係 一頭部X線規格側貌写真に 上る経年的研究一, 日矯歯誌 $28: 12-32$, 1969.

3. 山内和夫 -三宅通太 - 他：小学校児童頭蓋の成長変 化 II . 上顔面複合体と下顎との対応関係なら びに中切歯, 第 1 大臼歯について，

広大歯誌 $4: 32-44,1972$.

4. 矢野由人 - 神山光男 : 上顎前突の症例, 歯界展望 $24: 531-539,1964$.

5. 曾根静男 - 大野肃英・他：咬合斜面板を用いた 4 症 例について，日矯歯誌 $25: 238-251 ， 1966$.

6. 中島昭彦・久保田悦生・他：下顎前方誘導に伴う顎 顔面頭蓋の形態変化に関する研究 I . 側貌頭 部X線規格写真による角度の計測, 日矯柬誌 $36: 21-33,1977$.

7. Mearch, C.L. : A cephalometric comrarison of bony profile changes in Class II , divisison I patients treated with extraoral force and functional jaw or thope- 
dics, Amer. J. Orthodont. $52: 353-370$, 1966.

8. 三浦不二夫・坂本敏陔・他：機能的影矯正法に上 る上顎前突の治験成績 一頭部 X線規格'马真法 による検討一，日矯歯誌 $21 ： 114-120 ， 1961$

9. 三森紀夫・小森炤二：著しい過蓋咬合を伴ったII 級 I 類の 1 治験例, 日矯蔝誌 $23: 104-109$, 1964.

10. Bahador, M. A. and Higley, L. B. : Bite openning : A cephalometric analysis, J. Amer . Dent . Ass. 31: 343-352,1944.

11. 矢野由人 - 神山光男 : 過蓋咬合の症例, 霜界展望
$23: 899-909,1964$.

12. 小森昭二：咬合挙上における成長利用の効果 一咬合挙上板による治験例より一，霜界展望 $36: 988-993,1970$.

13.中島昭彥・緒方ゆりや・他：下顎前方誘導に伴う 顎顔面頭蓋の形態変化江関する研究 II . 側貌 頭部X線規格写真による距離の計測, 日矯菌誌 $36: 53-63,1977$.

14. 坂本敏彦・三浦不二夫・他：頭部エックス線規格 写真法による日本人顔面頭蓋の成長㳊関する研 究 一実測長分析, 成長率分析, 実測長百分率 分析成績一, 口病誌 $30: 169-182,1963$. 